\title{
Legitimacy, Signature and Sovereignty in Derrida
}

Andro Kitus

Queen Mary University of London, UK

\section{Abstract}

Legitimacy is a concept that has been largely forgotten by the deconstructive discourse on law and politics. This article seeks, on the one hand, to reassess the role of legitimacy in deconstruction and, on the other hand, to bring deconstructive thinking to bear on the concept of legitimacy. By re-reading Derrida's "Declarations of Independence” through the lenses of his later texts on sovereignty and (counter)signature, it is argued that, rather than being deconstructible, legitimacy is deconstructing any self-founding of law and power. As such, legitimacy functions not as an evaluative concept of law and order but as a constantly insisting demand that facilitates the principles of responsibility and responsiveness.

Keywords: deconstruction; democracy; Derrida; law; legitimacy; signature; sovereignty

\section{Introduction}

Legitimacy is an important concept in political and legal theory, but it does not stand out as having any notable role to play in deconstructive discourse on law and politics, where the focus is on the difference between law and justice. ${ }^{1}$ In "Force of Law," Derrida writes: "Law is the element of calculation, and it is just that there be law, but justice is incalculable, it requires us to calculate with the incalculable.”2 In other words, if law is to be just, it has to consider what is the most unique and singular, that is, incalculable, in particular cases, which,

1. Traditionally, legitimacy is defined as a right to govern, for example: "Legitimacy is the foundation of such governmental power as is exercised both with a consciousness on the government's part that it has a right to govern and with some recognition by the governed of that right.” Dolf Sternberger, “Legitimacy,” in International Encyclopedia of the Social Sciences (David L. Sills and Robert K. Merton, eds.) (New York: Macmillan, 1968), p. 244.

2. Jacques Derrida, “Force of Law: The 'Mystical Foundation of Authority'," Cardozo Law Review 11 (1990), 947. 
however, contradicts law's intrinsic aim to be valid generally and universally, that is, calculably. In this discrimination between calculable law and singular justice, legitimacy appears to be left on the side of law, reminiscent of Max Weber's reduction of legitimacy to legality. ${ }^{3}$ In most cases, Derrida lists “legitimacy” together with other so-called “calculables”. For example, in "Force of Law," he argues for the "deconstructibility of law (droit), of legality, [and] legitimacy or legitimation,” and later, legitimacy appears in the series of “calculables” such as "law or right, legitimacy or legality, stabilizable and statutory, calculable, a system of regulated and coded prescriptions." 4 This is the usage of the concept of legitimacy that Jiř́ Přibán̆ reacts against, arguing that "legitimacy ... does not seem to be of the same genre as legality ... it is tied in some way to the notion of justice.” 5 Přibáň goes on to propose a concept of legitimacy as a narrative about justice that takes place between incalculable justice and calculable laws:

Legitimacy is a realization of justice in the form of narrative which, unlike law, cannot be immediately backed by state force or violence and belongs to the sphere of opinion, narrative rules, and rhetoric skills.... The legitimacy of law grows from the very sphere of difference between calculable law and incalculable justice; it grows as an effort to bridge a seemingly infinite gap between the ethical demands of justice,

3. Weber's well-known statement in this regard is: "Today the most common form of legitimacy is the belief in legality.” Max Weber, Economy and Society: An Outline of Interpretive Sociology (Guenther Roth and Claus Wittich, ed. and trans.) (Berkeley: University of California Press, 1978), p. 37.

4. Derrida, “Force of Law,” p. 945, 959.

5. Jiří Přibáň, "Beyond Procedural Legitimation: Legality and Its 'Infictions'," Journal of Law and Society, 24 (3) (1997), 341. 
articulated from the singularity of individual being, and the impersonal system of general legal rules and procedure. ${ }^{6}$

I certainly concur with Přibáň’s hesitation toward merging legitimacy and legality, but it remains questionable that his proposed concept of legitimacy sides with justice rather than law if it is depicted merely as a fictitious and open narrative that aims to bridge the gap between law and justice - how would legitimacy as an opinion, for example, maintain its critical force in relation to law? In contrast, I argue that only when legitimacy is conceived as the very source of aporias in law and order, as a "site" where a gap in "the right to rule" emanates, which is not simply reducible to illegitimacy, it can be disentangled from the order of law. In that case, legitimacy does not intervene into law and order as an evaluation or critique, but as its condition of possibility and impossibility, which is to say that legitimacy, rather than being deconstructible, is deconstructing any self-founding of power or law. On the one hand, I claim that the possibility of such understanding of legitimacy is already prefigured in "Declarations of Independence," in one of Derrida’s earliest exercises on political theory that was first delivered as a public lecture in $1976 .{ }^{7}$ On the other hand, I show that Derrida marks out the site of deconstructive intervention in that text but does not conclude it. By bringing Derrida's later texts on signature and on sovereignty to bear upon this earlier text of his, I am going to demonstrate how the deconstructive intervention in that text can be completed, and how this results in a deconstructed ("concept" of) legitimacy, resigning.

By revealing legitimacy as resigning, I will not create another conception of legitimacy but withdraw legitimacy from the order of conceptuality in general. In other words, I do not intend to show how legitimacy is affected by aporias marked by Derridean

6. Přibán̆, “Beyond Procedural Legitimation,” p. 342.

7. See, Jacques Derrida, “Declarations of Independence,” in Negotiations: Interventions and Interviews, 1971-2001 (Elizabeth Rottenberg, ed. and trans.) (Stanford: Stanford University Press, 2002), p. 388. 
“infrastructures” as différance, re-mark, supplementarity, yes-yes, autoimmunity, and others, but that legitimacy itself functions as an "infrastructure” resigning in the political field. ${ }^{8}$ In doing this I also hope to bring into greater relief deconstruction's political relevance. As long as deconstruction does not show its movement in concepts that are central to the way we perceive our political and legal world, it always remains to a certain extent apart from this world and "merely" a philosophy; for example, in order to embrace the political consequences of auto-immunity, one has to be already a deconstructivist - its relevance is not immediately felt - but to argue the same about legitimacy might have different consequences, as it is a central concept in the political/legal realm itself.

I start my exposition with the idea of circularity of legitimate sovereignty that Derrida discusses in Rogues: Two Essays on Reason, which establishes a principle of reading for the following analysis of the founding signature in his text "Declarations of Independence.” Eventually, I will show that legitimacy transforms from being an evaluative concept of law and order to a generative "movement” that facilitates the principles of responsibility and responsiveness.

\section{The Circularity of Democratic/Legitimate Sovereignty}

Derrida briefly mentions the term "legitimacy" in the context of his critique of sovereignty understood as a mastery over oneself and others in one of his last published books Rogues: Two Essays on Reason. Derrida calls this mastery also ipseity that refers to “some 'I can,' or at the very least the power that gives itself its own law, its force of law, its self-

8. On the systematic usage of the notion "infrastructure" in the context of deconstruction, see Rodolphe Gasché, The Tain of the Mirror: Derrida and the Philosophy of Reflection (Cambridge, MA and London: Harvard University Press, 1986), esp. pp. 142-154. 
representation.”9 Thus, the ipseity at the center of the modern concept of sovereignty names "before any sovereignty of the state, of the nation-state, of the monarch, or, in democracy, of the people ... a principle of legitimate sovereignty, the accredited or recognized supremacy of a power or a force.” ${ }^{10}$ This is to say that before any legitimate sovereignty can come to exist, it must have been able to grant a right for and to itself. However, this self-creation or selflegitimizing contains seeds of its own downfall because it is conceivable only on the basis of a return to the source.

Let us unpack three movements in the granting of a right for and to oneself. In the first movement, by Derrida’s words, "the first turn or first go-round of circularity or sphericity comes back round or links back up, so to speak, with itself, with the same, the self, and with the proper of the oneself, with what is proper to the oneself proper." ${ }^{11}$ Hence, first, there is a turn, but in its second movement, this turn immediately must be also a return to the source that is "implied, posed, presupposed, but also imposed in the very position, in the very self- or auto-positioning, of ipseity itself [-] everywhere there is some oneself, the first, ultimate, and supreme source of every 'reason of the strongest' as the right [droit] granted to force or the force granted to law [droit].”12 The problem is that whatever returns must have been missing in the place where it returns, for what is absolutely present to itself must not "go out" to arrive at itself. Therefore, the turn and return together must form a circle or circling (as if along the surface of a sphere), so as to allow sovereignty to appear in its instantaneousness, hiding the gap in the source: "The turn makes up the whole and makes a whole with itself; it consists in totalizing, in totalizing itself, and thus in gathering itself by tending toward simultaneity; and

9. Jacques Derrida, Rogues: Two Essays on Reason (Pascale-Anne Brault and Michael Naas, trans.) (Stanford: Stanford University Press, 2005), p. 11.

10. Derrida, Rogues, p. 12.

11. Op. cit., p. 12.

12. Ibid. 
it is thus that the turn, as a whole, is one with itself, together with itself." ${ }^{13}$ Nevertheless, as Derrida shows, this closing of the circle cannot take place without the return, that is, without opening the circle towards the outside. Derrida develops this thought toward the aporia of auto-immunity, where immunity that is meant to protect the inside, necessarily turns on itself, opening the closed up circle of turns "to the other, to what and to who comes."14

As the following analysis does not hinge on the thought of autoimmunity, I will not expand this line of argument further here. This article follows a different trajectory but that is also implicit in the figure of circular sovereignty. As soon as there is something returning or coming back, its origin in the self-same source needs to be validated. This validation would be marked by a signature that closes the circle, effecting the return to the source. The possibility of signature becomes then the possibility of legitimacy. However, as the signature itself falls under the requirement to be legitimate, authorized in the first place, this leads to an unsatisfactory circle: one cannot decide which comes first, signature or legitimacy, whether signature adds itself to and completes the circle of legitimate sovereignty from the outside or it already belongs inside the circle of legitimate sovereignty.

Rather than interpreting this as the dead end of the inquiry, I consider it as an invitation to think legitimacy and signature together in one structure. This means taking one step still further and demonstrating that signature cannot be thought neither inside nor outside the circle of legitimate sovereignty, even if it is still absolutely necessary. ${ }^{15}$ Neither/nor erases the anteriority of signing in relation to legitimacy, in which case the "logic" of signing folds into the structure of legitimacy. This will be shown in the following discussion of Derrida's

13. Ibid.

14. Op. cit., p. 152.

15. On the use of 'neither/nor' in Derrida, see Jacques Derrida, "Khôra," in On the Name (Thomas Dutoit, ed.) (Ian McLeod, trans.) (Stanford: Stanford University Press, 1995), pp. 89-127. 
analysis of the paradox of the founding acts or signatures of democratic states in his text of “Declarations of Independence.” It will bring together the themes of legitimate sovereignty and the founding signature, which then allows me to propose a critique of the traditional concept of legitimacy understood as the moment of closure of the circle of legitimate sovereignty, and eventually argue that the circle of turns and returns of sovereignty is closed and opened by legitimacy as resigning.

\section{The Undecidable Turn/Return in "Declarations of Independence"}

Derrida’s text of “Declarations of Independence” offers an interpretation of the paradox that has plagued the democratic founding act from the very moment democratic legitimacy turned into a problem for political theory. Around the $16^{\text {th }}-17^{\text {th }}$ centuries, the belief in the divine or natural right of the few to rule over the rest starts to wane and is replaced gradually by the belief that any such rule needs to be justified, legitimized. ${ }^{16}$ Jean-Jacques Rousseau, one of the first to recognize the problem generated by this new development, formulates a great task for the new era: “To find a form of government that might place the law above man." ${ }^{17}$ Later, the paradox is given a more precise articulation by Abbe Sieyès who attempted to solve it for the French Revolution in terms of constitutive and constituted powers and dubbed it the “vicious circle,” the petitio principii. ${ }^{18}$ The paradox that appears in the democratic founding

16. See, for example, Richard E. Flathman, "Legitimacy,” in A Companion to Contemporary Political Philosophy (Robert E. Goodin, Philip Pettit and Thomas Pogge, eds.) (Malden, Oxford, Carlton: Blackwell, 2007), p. 678.

17. Jean-Jacques Rousseau, The Social Contract and Other Later Political Writings (Victor Gourevitch, ed.) (Cambridge: Cambridge University Press, 1997 [1767]), p. 270.

18. Emmanuel Joseph Sieyès, "What is the Third Estate,” in Political Writings: Including the Debate between Sieyès and Tom Paine in 1791 (Michael Sonenscher, ed. and trans.) (Indianapolis and Cambridge: Hackett, 2003 [1789]), pp. 34, 139. Hannah Arendt, who 
act is as follows: the people have no authority to sign the declaration that creates their freedom, because it is only after the declaration is signed that they can have this authority. It seems that the legitimate democratic founding act is impossible.

Derrida's approach to the "vicious circle" of democratic founding can be recast in terms of the same logic of turn and return as developed in his critique of sovereignty. ${ }^{19}$ Firstly, there is an act of proposing the declaration that is to grant freedom to the people, and secondly, the people, by proxy of their representatives sign the declaration of their independence, attesting the presence of their will and intent in that document, in which case the declaration as if turns back to its source, to the people, founding a sovereign and autonomous entity. This is a full turn. Its constitutive elements are the declaration that is

has also dealt with this paradox in her On Revolution, succinctly summarizes Sieyès’s approach: For Sieyès, "both power and law were anchored in the nation, or rather in the will of the nation, which itself remained outside and above all governments and all laws.” Hannah Arendt, On Revolution (London: Penguin Books, 1990), pp. 162-63. So, in essence, Sieyès replaced the sovereignty of the king with the sovereignty of the nation. There is no space here to outline Arendt's own, a quite different answer, but as a remark be it said, she grounds the founding act on the simultaneity of the beginning and the principle that supports it. See, Arendt, On Revolution, p. 212; for the comparison between Derrida and Arendt see, Bonnie Honig, "Declarations of Independence: Arendt and Derrida on the Problem of Founding a Republic,” The American Political Science Review, 85 (1) (1991), 97-113.

19. See also an analysis of "Declarations of Independence" from the point of view of constitutional theory by Jacques de Ville, “Sovereignty without Sovereignty: Derrida’s 'Declarations of Independence'," Law and Critique 19 (2008), 87-114. 
(always) departing and arriving back, ${ }^{20}$ the people as the presumed source and destination of the declaration, and the signature as the turning point (or equally, the point of no return), at which the declaration bends back to the source (or not).

As mentioned, this (first) full turn is affected by the paradox of the vicious circle, and Derrida admits this: “The 'we' of the Declaration speaks 'in the name of the people'. But these people do not exist. They do not exist as an entity, the entity does not exist before this declaration, not as such." ${ }^{21}$ This means that if the people indeed come to be, they are only the effect of the turn (and return), but the turn itself must have its "source" in the signature; it is "the signature [that] invents the signer." ${ }^{22}$ This is possible, as Derrida explains, on the basis of a certain retroaction, of the future perfect tense: at the moment when the signing of the founding act arrives at its end, so to say, the signers, "henceforth, have the right to sign”, which amounts to an aporia, and therefore, “in truth, [they] will already have had it since [they were] able to give it to [themselves]."23

The phrase "will already have had the right” signals that the declaration has to be conceived as already returning. The declaration as if had been already signed before, and now, it returned again to the people, confirming their freedom. The first turn of the declaration must already be a return, or rather - as the turn cannot be just replaced by a return -, there has to be a sort of undecidability between the turn and return: "one cannot decide ... whether

20. This is to say that the circling of the declaration continues beyond the founding act to "guarantee your passport and the circulation of subjects and of seals foreign to this country, of letters, of promises, of marriages, of checks.” Derrida, "Declarations of Independence,” p. 51.

21. Op. cit., p. 49.

22. Op. cit., pp. 49-50.

23. Op. cit., p. 50 . 
independence is stated or produced by this utterance.”24 In other words, it remains unclear whether the Declaration creates the freedom of the people or only confirms it being the fact. Derrida adds that "it is not a question here of an obscurity or of a difficulty of interpretation," but it is a necessary undecidability that "is required to produce the sought-after effect. It is essential to the very positing or position of a right as such.” ${ }^{25}$ It is necessary because this undecidability is what creates the motion or force of circling, the rotational movement, the constant movement of one turn chasing another.

What adds another layer of complicacy is that the movement of circling should not be noticed, or in Derrida's text, the retroaction in signing of the declaration "should not be declared, mentioned, taken into account.” ${ }^{26}$ The circling should form a closed circle, a simultaneity of turns and returns, of the performative and constative, because as long as there is a degree of alternation of or a duration between turns and returns, it exposes a lack in the presumed source of right, showing that the source itself has to be legitimated. Derrida argues that in order to hide its delegitimizing "coup de force," retroactivity must present itself in "the simulacrum of the instant," which is achieved by a fable that covers up temporality of the act of retroaction - hence, a “fabulous retroactivity.”27 To use Richard Beardsworth’s expression, the fable effectuates the "disavowal of time.”28 Derrida shows that the text of American

24. Op. cit., p. 49.

25. Ibid. Derrida’s analysis takes place against the background of his critique of J. L. Austin's theory of speech acts; for an extensive discussion of Austin's concepts of “performatives” and “constatives,” see Jacques Derrida, Limited, Inc. (Samuel Weber, trans.) (Evanston, IL: Northwestern University Press, 1988).

26. Derrida, “Declarations of Independence,” p. 50.

27. Op. cit., p. 50.

28. Richard Beardsworth, Derrida \& the Political (London and New York: Routledge, 1996), p. 101. 
Declaration of Independence cannot do without references to fables, like laws of nature, God's will, or immemorial tradition, the role of which are to hide the operation of retroactivity and to invent the game "that tends to present performative utterances, as constative utterances.”29 Thus, the signature under the Declaration still is as if countersigned by some absolute authority beyond the need of further authorization, from which the best one, as Derrida says, the most ultimate one, is God. ${ }^{30}$ By extension, one might say that every founding act, every “originary beginning” needs (a fable of) god (or nature, subject, language, tradition) to sign in the last instance.

This conclusion has been often considered as an “official” end of Derrida’s engagement with the text of American Declaration of Independence. ${ }^{31}$ If this is the case, however, the text clearly does not end with a deconstructive intervention into the founding act; it stops at the undecidability between producing and confirming the freedom of the American people. Even if the undecidability demonstrates an internal undoing of every declaration of independence, it equally demonstrates their effectiveness.

The context of its publication should not be forgotten: it was first presented as an introduction to the public lecture on Friedrich Nietzsche at the University of Virginia in Charlottesville in 1976 on the occasion of the 200th anniversary of the American Declaration of Independence, that is, as an event in the chain of celebrations of the Declaration. ${ }^{32}$ Derrida seems to suggest that the force of the declaration that binds people and is constantly binding

29. Derrida, “Declarations of Independence,” p. 51.

30. Op. cit., p. 52.

31. See, for example, Noah Horwitz, "Derrida and the Aporia of the Political, or the Theologico- Political Dimension of Deconstruction,” Research in Phenomenology, 32 (1) (2002), 156-76.

32. See, Geoffrey Bennington, Interrupting Derrida (London and New York: Routledge, 2000), p. 29. 
them to such declarations is that the question remains open: "Is it that the good people have already freed themselves in fact and are only stating the fact of this emancipation in the Declaration? Or is it rather that they free themselves at the instant of and by the signature of this Declaration?”33 The undecidability empowers the declaration to organize people around itself, and thus, preserves it and keeps it alive. In his text, Derrida focuses on the political significance of declarations, and therefore, he does not venture beyond the undecidability that is more like "oscillation between two significations, or two contradictory and very determinate rules, each equally imperative,” but is not undecidability in its infrastructural sense. $^{34}$

Derrida knows all that. He signals his withdrawal from the deconstructive intervention in the end of the text: "I will not, in spite of my promise, engage myself on this path today."35 But he also adds a qualification to the conclusion of the text that complicates its simplicity. Namely, he crosses out God's signature: “God ... had nothing to do with any of this and, having represented God-knows-whom-or-what in the interest of all those nice people, no doubt could not care less.” ${ }^{36}$ He seems to suggest that even if this is how founding acts might have appeared in history, supported by absolutes, this does not have a hold for us anymore. But if there is no God to sign ultimately, the question remains open: “who signs?”. So it is that Derrida's text on the American Declaration of Independence starts with the question, "who signs, and with what so-called proper name, the declarative act that founds an institution?”, and the texts ends with the same question: “Who signs all of these authorizations

33. Derrida, “Declarations of Independence,” p. 49.

34. Derrida, “Force of Law,” p. 963.

35. Derrida, “Declarations of Independence,” p. 53.

36. Op. cit., p. 53. 
to sign?”37 It is as if these two questions mark out the site of a possible deconstructive intervention, but the intervention itself remains uncompleted.

In Positions, Derrida explains that "the incision of deconstruction ... can be made only according to lines of force and forces of rupture that are localizable in the discourse to be deconstructed.” ${ }^{38}$ In the text of the Declaration such line of rupture is marked by the question “who signs?”. Therefore, the first step in making the incision of deconstruction into the democratic founding act and legitimacy in the context of American Declaration of Independence is to show that the question "who signs?" points to an aporia in the logic of the founding (counter)signature. This requires taking a step back from where Derrida simply crossed out God's countersignature and showing that the ultimate placeholder of the signature necessarily fails under its own weight to guarantee the signature. This is what I will address in the following part.

\section{The Failure of the Countersignature}

Every countersigning by an additional signature remains affected by the same logic as the “originary” signature, demanding still further authorization. Therefore, in time, there are only (counter)signatures, and the arrival of the signature is endlessly deferred. For that reason, it might seem that the countersignature of God is the best one, for it requires by definition no further authorization. The role of God's (or any other absolute's) countersignature is to cast the retroaction in signing the declaration as "the simulacrum of the instant," or, put in terms of circular sovereignty, to erase time in the circling of turns and returns, making them overlap. ${ }^{39}$ If the countersignature of God is to fail, this must concern its inability to erase time.

37. Op. cit., p. 50.

38. Jacques Derrida, Positions (Alan Bass, trans.) (London and New York: Continuum, 2004), p. 68.

39. Derrida, “Declarations of Independence,” p. 51. 
A closer examination of what happens with the dimension of time when God countersigns shows that two different movements take place at the same time. On the one hand, at the moment of God's countersignature, the people appear already freed by God's grace, as if the people create their freedom inside God's "grand plan.” On the other hand, God's signature is the last instance only in so far as it is given outside time, which makes it, literally, timeless. Therefore, simultaneously with God’s countersigning and producing “the simulacrum of the instant" in the authorization of the declaration, God also creates the “eternal time” of the people - at the moment of the countersignature, the people appear always already freed, as if from the time immemorial.

This eternal time of the people emerges in the very instant of the founding act. It cannot be thought to exist prior to the instant or somehow after it, and therefore, the instant itself must be divided from the very outset by the eternal time. This means that the very instantaneousness of the instant, which allows us to think simultaneity of turns and returns, or of the signing and its authorization, is put into question by the eternal time. We can think this in terms of delay. Since such delay cannot be directly perceived (that is, without comparison), it must "occur" as an internal moment of the signature, which is to say that at the moment of its appearance, the signature is already delayed, it appears as late, not in the "right" time.

The delay can be witnessed in a temporal as well as spatial gap (as différance) between every signature and every text. A signature, as soon as it is added to a text, does not hold together with the text, because signing takes place later (or in advance) than writing of the text to be signed, and also below (or above) that text, that is, outside the text. This fundamentally undermines the signature, because the text, for example, a declaration, was first written violently outside the limits of authorization. Beardsworth offers the same insight in the context of law: "The unsurpassable violence of law (its aporia) is predicated on the delay 
of time. An act of legislation always arrives too early and/or too late.” ${ }^{40}$ And, as Derrida shows, one cannot sign in the text:

By not letting the signature fall outside the text any more, as an undersigned subscription, and by inserting it into the body of the text, you monumentalize, institute, and erect it into a thing or a stony object. But in doing so, you also lose the identity, the title of ownership over the text: you let it become a moment or a part of the text, as a thing or a common noun. ${ }^{41}$

This means that if the signature is inserted in the text, it disappears; if it is left outside the text, it loses its authorization.

Thus, the founding signature is delayed, constitutively delayed; it is late to itself, so to say. God countersigns, but the signature under the declaration, nevertheless, does not arrive at the "right" time. Consequently, the ultimate countersignature is failing to guarantee the founding act, because the question of "who signs?” resurfaces in the radical manner. As soon as the people are "always already" free by the grace of God, there is no univocal relation to the signer who was to sign in fact, that is, whose signature was to be countersigned. Therefore, the question emerges, who represents the people (and which people) in their eternal time; who among them is to sign the declaration, because there is no one by right to sign the declaration that equally produces and confirms the freedom of the people. In other words, the whole history of freedom of the people that was invented with "the eternal time" undermines every signature that is proposed to sign the declaration, and the question "who signs?” is haunting from the very beginning, affecting the internal structure of the founding act.

40. Beardsworth, Derrida \& the Political, p. 100.

41. Jacques Derrida, Signéponge = Signsponge (Richard Rand, trans.) (New York: Columbia University Press, 1984), p. 56. 
It follows that solely on the basis of the countersignature, even if given by God (or any other absolute), the founding act does not yet emerge; it is as if put on hold. On the one hand, if the countersignature is given outside time, that is, by an absolute, the founding signature appears as delayed. On the other hand, if the countersignature is given within time, it always needs a further countersignature to authorize the existing one, so that the signature remains eternally deferred. The signature is always yet to come, or still to be remembered. In that way, signature cannot originate neither inside the circle of legitimate signature as a countersignature, nor outside of it when backed by an absolute. In the next section, I will return to the question of legitimacy to show how the ultimate failure of the (counter)signature dislocates its traditional concept.

\section{The Critique of Legitimacy}

In terms of “a principle of legitimate sovereignty," that is, in terms of an ability or power to grant a right for and to himself, the main consequence of the delay of the (counter)signature is that the return and the turn never overlap to form a circle, and the lack in the presumed source of right is never covered up. All its elements, that is, the people, the declaration, the signature appear in need to be legitimated, which means that the principle of legitimate sovereignty cannot be located inside or outside the circle of turns and returns, but it must, in a certain sense, "precede” the circle as its condition of possibility and impossibility. This, however, calls for a different concept of legitimacy.

The idea that the source of right, the people itself, needs to be legitimated is by no means a new idea. Sofia Näsström argues that "political authority must be prior to the citizens and simultaneous with the citizens at the same time," which means that "the people is no longer the source, but the object, of legitimacy.”42 I agree with this position, but I also argue that this affects the concept of legitimacy itself. In order to unfold what this new concept of

42. Sofia Näsström, “The Legitimacy of the People,” Political Theory, 35 (5) (2007), 641. 
legitimacy entails, I first transcribe the founding act in terms of decision, which reveals a path to the criticism of the traditional concept of legitimacy.

In “Countersignature,” Derrida remarks that "thinking the signature is inseparable from thinking the decision and the moment of decision." ${ }^{43}$ The latter is well expounded in "Force of Law," where he argues that if a decision were to follow a rule, a prescription, or a certain logic, it would not be decision but a "programmable application or unfolding of a calculable process.” ${ }^{44}$ In order to be worthy of its name, the decision must be preceded by risk, uncertainty, openness, in short, undecidability. There is only a decision when one does not know which way to go. But this also means that when the signature is successful, its "ground" in the undecidability is not erased but continues to affect it:

The undecidable remains caught, lodged, at least as a ghost - but an essential ghost in every decision, in every event of decision. Its ghostliness deconstructs from within any assurance of presence, any certitude or any supposed criteriology that would assure us of the justice of a decision, in truth of the very event of a decision. ${ }^{45}$ Recasting the signature in terms of decision, highlights that any founding act, understood as an event, must have a possibility to fail, because, otherwise, it would be a mere calculable projection, which always arrives at its destination. Since the people as an entity does not exist prior to the signing of the declaration, the failure of the signature to found the freedom of the people is the failure to create the very entity on the basis of which the failure could have been recognized. Hence, the founding signature that creates its own authorization, and that exists only due to this authorization, can appear, paradoxically, only as a successful signature, because the failure of the signature, strictly speaking, cannot be known; it does not appear. As much as the possibility of the failure of the signature still is the very condition of its success

43. Jacques Derrida, “Countersignature,” Paragraph, 27 (2) (2004), 38.

44. Derrida, “Force of Law,” p. 963.

45. Op. cit., p. 965. 
as a creative act, its failure cannot be understood as a simple non-recognition or illegitimacy (of a once successful signature) but only as a non-presence in the signature itself. And even if the signature is successful in achieving its recognition, and the founding act comes into existence, the non-presence cannot be erased from its structure; it must continue "haunting" the successful signature (if there is one).

I argue that the same "movement” of non-presence must be included in the concept of legitimacy if the latter is to function as the condition of possibility and impossibility of the circular sovereignty. The traditional discourse on legitimacy has overlooked the possibility of such "movement" in the act of legitimation. The fact that legitimacy has always contained a certain self-erasure in its functioning can be inferred from a simple observation: if legitimacy is said to be present, then what is in fact present is what legitimacy is attributed to, that is, in most general terms, a political order or a system of laws. Legitimacy as if "slides under" that order or system that then functions according to its own rules and logic. ${ }^{46}$ However, at the same time, legitimacy is not considered to be withdrawn from that order but is present in its non-presence. To a certain extent, this movement has been noticed by different political theorists. For example, Rodney Barker, discussing the work of Seymour Lipset, notes: "Legitimacy as a term is used when its absence is identified rather than when its presence is described. It is the normal and unremarked characteristic of liberal democratic societies, and is, like the air we breathe, only commented upon when it turns nasty." ${ }^{47}$ Also, Habermas

46. The phrase “slides under” alludes to Jacques Lacan’s expression “an incessant sliding [glissement] of the signified under the signifier,” which means that meaning in language emerges as the effect of play of signifiers, rather than in relation to some external referent. Jacques Lacan, Écrits: A Selection (Alan Sheridan, trans.) (London and New York: Routledge, 2005), p. 117.

47. Rodney Barker, Political Legitimacy and the State (Oxford: Clarendon Press, 1990), p. 76. 
makes a similar remark, saying "historically as well as analytically, the concept is used above all in situations in which the legitimacy of an order is disputed, in which, as we say, legitimation problems arise." ${ }^{48}$ However, even if noticed, there are no means to account for this movement in traditional theories, because ever since legitimacy became a political problem, it has been theorized on the basis of the question "what is?” legitimacy.

The question “what is?” legitimacy must presume the presence of an order to which the criteria or principles of legitimacy are applied later. In its formal structure, the concept of legitimacy that follows from that question refers to the congruence between certain empirically or normatively deduced values and action(s) of the government. ${ }^{49}$ Even if we assume that the founding act of a political institution or law of laws is grounded on certain principles or criteria that allow the confirmation of its legitimacy, the presence of these criteria at the founding moment does not predetermine their being followed in every subsequent act. The law or power does not function as an automatically released script but as a repetition. But in that case, legitimacy does not stand as a condition of law and order, as producing them, on the contrary, its intervention (claim of in/validity) presumes that there is a law and an order in force. The label "legitimate" is a positive evaluation (or a test result) that these two sides of value and action coincide, grounding in such a way a demand for voluntary obedience to an order or to a system of laws. Hence, legitimacy becomes understood as an “evaluative concept” (Lipset), or a “contestable validity claim” (Habermas), because it can

48. Jürgen Habermas, "Legitimation Problems in the Modern State,” in Communication and the Evolution of Society (Jürgen Habermas, ed.) (Boston: Beacon Press, 1979), pp. 17879.

49. See, for example, Peter G. Stillman, “The Concept of Legitimacy,” Polity 7 (1) (1974), 32-56: “A government is legitimate if and only if the results of governmental output are compatible with the value patterns of the society." 
intervene only after the fact. ${ }^{50}$ But if this is so, the concept of legitimacy is susceptible to the same critique that Derrida launches against the Husserlian concept of sign:

By asking "What is the sign in general?", we raise the question of the sign to an ontological plane, we pretend to assign a fundamental or regional place to signification in an ontology. This would be a classical procedure. One would subject sign to truth, language to being, speech to thought, and writing to speech. To say that there could be a truth for the sign in general, does this not suppose that the sign is not the possibility of truth, does not constitute it, but is satisfied to signify it - to reproduce, incarnate, secondarily inscribe, or refer to it? ${ }^{51}$

The same objection can be raised against the concept of legitimacy above: if one starts with the question “what is?” legitimacy, the latter is reduced to a signification of a political order, but it does not create it. In order to give to legitimacy its potential generative role, the concept of legitimacy is needed that is able to contain the movement of self-erasure in it. Paraphrasing Derrida's similar question on the sign, we could ask: Is not legitimacy something other than a being ... [which] does not fall under the question "what is...?” but on the contrary, should the occasion arise, produces "politics" in this way as the empire of the ti esti? ${ }^{52}$

In that case, any political order or system of laws, or in general, any sovereignty, can never hold on to legitimacy as its own, for legitimacy contains its undoing not in an alternating fashion after a successful self-founding but concurrently with its founding.

50. Seymour Martin Lipset, Political Man: The Social Bases of Politics (Garden City, NY: Anchor Books, 1963), p. 64. Jürgen Habermas, “Legitimation Problems in the Modern State,” in Communication and the Evolution of Society (Jürgen Habermas, ed.) (Boston: Beacon Press, 1979), p. 178.

51. Jacques Derrida, Speech and Phenomena, and Other Essays on Husserl's Theory of Signs (David B. Allison, trans.) (Evanston: Northwestern University Press, 1973), p. 24.

52. Derrida, Speech and Phenomena, p. 25. 
Democratic sovereignty can refer to legitimacy only as its condition of possibility and impossibility. Such understanding of legitimacy will be developed by engaging further with the aporia of (counter)signature revealed above. It will be shown below that the logics of the aporetic founding signature and legitimacy fold into each other in the "movement" of resigning. The following exposition aims at giving a preliminary account of legitimacy as resigning, indicating the possibility and necessity for such understanding, but due to space limitations its full elaboration is left to other occasions.

\section{Resigning}

In chapter IV, it was concluded that the (counter)signature remains endlessly deferred or eternally inadequate. This, however, does not change anything about the fact that the effect of the (counter)signature is absolutely necessary. It is necessary not only because it creates the whole performative-constative play that guarantees the signature under the declaration, but also because there cannot be anything beyond the play of (counter)signatures that could come to rescue the democratic founding act. This is the site of the Derridean radical aporia: the (counter)signature is impossible and necessary at the same time. But precisely because there is no way around the aporia, no alternative route, it also forces us to decide, to realize, perhaps, or to take "a step beyond”, a step that is also a "not-step” - a "pas." 53 Therefore, the aporia does not denote a paralysis, but evokes what Derrida describes in Memoires for Paul de Man as "a call of memory”:

... an other memory calls us, recalls us to think an "act” or "parole” (speech), or a "speech act" which resists the opposition performative/constative, provoking at the

53. See, Jacques Derrida, Aporias: Dying - Awaiting (One Another At) the "Limits of Truth" (Thomas Dutoit, trans.) (Stanford: Stanford University Press, 1993), and Jacques Derrida, “Pace Not(s),” in Parages (John P. Leavey, ed. and trans.) (Stanford: Stanford University Press, 2003), pp. 11-102. 
same time the aporia and movement forward (la marche) ... this singular memory does not lead us back to any anteriority. There never existed (there will never have existed) any older or more original "third term" that we would have to recall, toward which we would be called to recall under the aporetic disjunction. This is why what resists the nondialectizable opposition, what "precedes" it in some way, will still bear the name of one of the terms and will maintain a rhetorical relation with the opposition. ${ }^{54}$

Following the same reasoning in the context of the aporia of the (counter)signature, we must assume that another "signature” of sorts paradoxically signs (and is always re-signing) to complete the signature by opening it to another signature. In other words, the aporia of the (counter)signature calls us to think an other "signature" or "signing” that in some way creates the order of (counter)signature itself by authorizing the delay or anticipation of the signature. This other "signature,” in an interesting loop, would make possible for the countersignature to bring the signature into effect. But it also opens it up to what is still to come. Thus, even if this other "signature" first must be thought to come and sign again in authorizing the declaration with all the names under it, it cannot itself become a (counter)signature but must withdraw from what it makes possible. There are two movements in one: it re-signs, that is, signs again, in order to effectuate the signature, but at the same time, while doing this, it resigns, that is, withdraws from what it makes possible. It has to be resigning in order to resign.

Derrida’s analysis in “Countersignature” arrives at the same movement, though, he does not refer to it as resigning but as a "suicidal signature”: “A signature destined to sign only to bring about its own effacement. That is, to attain, to arrive at its own effacement, but

54. Jacques Derrida and Paul De Man, Memoires for Paul de Man. Revised edition (Cecile Lindsay, Jonathan Culler, Eduardo Cadava and Peggy Kamuf, trans.) (New York: Columbia University Press, 1989), p. 137. 
also to come about, to happen, as its own effacement. Simultaneously event and effacement." 55 If resigning is not the same as, or synonymous to, "suicidal signature,” it is because the trajectory of deconstructive reading always remains part of its outcome and its intervention. Hence, deconstructive reading of the logic of signing that proceeds from the problematic of legitimacy of founding acts, declarations and signatures produces a different intervention - resigning - than the "same” reading on the basis of Jean Genet's poetry in “Countersignature.” It is because of this route we can conclude that resigning, by constituting the incision of deconstruction into the founding signature, also "names" a deconstructed “concept” of legitimacy: legitimacy as resigning. Saying it in this way, though, does not mean that resigning is a name given to a certain "logic” or "movement”, but it is revealed by deconstruction as the very "embodiment” of it.

The formula "legitimacy as resigning" does not say that there is another way for legitimacy to be, it only marks a "place” where re-signing at the same time resigns, or legitimacy withdraws. The question is how resigning produces effects in the phenomenal field, if it is simultaneously possible-impossible, if it re-signs and resigns. Firstly, we have to keep in mind that re-signing is not cancelled by resigning; re-signing is supposed to happen. We deal here with what Derrida says is "the im-possible event, an im-possible that is not merely impossible, that is not merely the opposite of possible, that is also the condition or chance of the possible.”56 Therefore, re-signing cannot be thought as arriving at its end, at its completion, for if this were the case, it would fully appear in the field of phenomenality. Instead, re-signing must remain happening, it must have emerged but remain, nevertheless, incomplete, unfinished, impossible. ${ }^{57}$ If it is said that re-signing precedes in some way the

55. Derrida, “Countersignature,” p. 38.

56. Jacques Derrida, “A Certain Impossible Possibility of Saying the Event,” Critical Inquiry 33 (2) (2007), 454.

57. See also, op. cit., p. 452. 
scene of signing, it must be taken a-temporally or anachronistically, because re-signing does not have an identity on its own to precede in the sense of coming first, however, if it is presumed given “eventually,” it always appears as if in some way “preceding” the (counter)signature.

However, secondly, as much as re-signing is still inevitable, resigning cannot be entirely absent from the field of phenomenality. It must remain, as it were, haunting, and Derrida argues that "this haunting is the spectral structure of this experience of the event; it is absolutely essential.”58 What remains haunting is the very necessity of re-signing, because resigning, being not able to arrive at its end, always leaves a doubt, a question whether something has been (re-)signed or not. In fact, this very unclarity is constitutive of the demand, or as Derrida puts it, rephrasing Blanchot’s thought: “[The demand] can never be always present, it can be, only, if there is any, it can be only possible, it must even remain a can-be or maybe in order to remain a demand."59 Therefore, as a result of this indecision, there is a certain haunting (internalized and infinite) urgency or demand to re-sign, to be ready or prepare oneself to re-signing. ${ }^{60}$

In the political context, legitimacy as resigning becomes the condition of possibility and impossibility of the right to rule. On the one hand, legitimacy, by always withdrawing

58. Op. cit., p. 453.

59. Jacques Derrida, Specters of Marx: The State of the Debt, the Work of Mourning and the New International (Peggy Kamuf, trans.) (London: Routledge, 2006), p. 39.

60. This thought lies at least in close proximity to Levinas' understanding of the ethical subject. According to Simon Critchley’s rendering, "the Levinasian ethical subject, is a subject defined by the experience of an internalized demand that it can never meet, a demand that exceeds it, what he calls infinite responsibility.” Simon Critchley, Infinitely Demanding: Ethics of Commitment, Politics of Resistance (London and New York: Verso, 2008), p. 10. 
from what it makes possible, clears in its place an infinite demand for there to be a right to rule. On the other hand, the right to rule remains always yet to be ascertained, and in its state of being or coming, it can only exist as a right to respond, a right to care for any one or what is to come to resign the right to rule. In this way, legitimacy as resigning counteracts the negative implication of the traditional concept of legitimacy to develop into a justification of state violence and promoting a sense of complacency in the people. ${ }^{61}$ Legitimacy as resigning is not a mandate for someone to rule over others or not but a "space" of the demand or call for re-signing - a certain openness to every possible signer. It is because there cannot be any expectation or determination who or what comes to re-sign the declaration and its signatures at the moment of the aporia of (counter)signature. But importantly, even when the declaration appears signed, it still is impacted by a (haunting) demand to remain open to re-signing by each and every one, because there is no guarantee or certainty that re-signing has taken place. This openness to re-signing affects all stakeholders in the legitimation process: on the one hand, it insists that people re-sign with all the responsibility this entails, on the other hand, it requires from governments to accommodate re-signing (that is always still to be concluded) with all the responsiveness this involves.

Understood in this way, legitimacy is not a concept that establishes measurable conditions to evaluate a political order or action but what insists as a first positing of the demand that there be a rightfulness of rule; before any determination, legitimacy demands “there must be” a right to rule. Legitimacy thus thinks “originary ethics” as explicated by Jean-Luc Nancy in his commentary of Martin Heidegger’s philosophy. Nancy states that “it isn’t philosophy's job to prescribe norms or values: instead, it must think the essence or the

61. For example, Michel Foucault highlights the role of legitimacy in hiding domination in power relations, see his “Two Lectures,” in Power/Knowledge: Selected Interviews and Other Writings 1972-1977 (Colin Gordon, ed. and trans.) (New York: Pantheon Books, 1980), pp. 96-97. 
sense of what makes up action [l'agir] as such; it should think, in other words, the essence or the sense of what puts action in the position of having to choose norms or values.” 62 Legitimacy as resigning is precisely what submits political actions (of governments and people) under the unconditional requirement to continuously choose norms or values in responding to the other who must be welcomed. Therefore, by putting legitimacy as a concept under erasure, resigning becomes a generation of political responsibility and responsiveness.

In terms of the circling of turns and returns of the legitimate sovereignty, resigning appears as the cause of both, of closing and opening the circle, or put differently, the circle of turns and returns can never be formed without opening it to the outside at the same time. In this way, legitimacy as resigning, instead of belonging into the order of laws, rules, prescription, and so forth, adds itself to the infrastructural chain with différance, re-mark, supplementarity, yes-yes, autoimmunity, and others, as their "nonsynonymous substitution.”"63 Legitimacy is a deconstruction of any self-founding, self-delegation or -representation, or self-governing by a sovereign who gives a right for and to itself.

\section{Conclusion}

The aim of the article was twofold. It engaged with Derrida's early text "Declarations of Independence” to complete the deconstructive intervention into the democratic founding act, and it sought to rethink the position of legitimacy in the deconstructive discourse on law and politics where it appears on the side of law, rather than justice. My argument was that these two tasks fold into each other, so that the incision of deconstruction into the democratic founding act amounts to a deconstructed “concept” of legitimacy that untangles legitimacy

62. Jean-Luc Nancy, “Originary Ethics,” in his A Finite Thinking (Simon Sparks, ed., Duncan Large, trans.) (Stanford, CA: Stanford University Press, 2003), p. 173.

63. Jacques Derrida, “Différance,” in Margins of Philosophy (Alan Bass, trans.) (Brighton: The Harvester Press. 1982), p. 12. 
from the order of law. I proposed that legitimacy (is) resigning; it re-signs and resigns at the same moment, so that it never comes to exist, but still is absolutely necessary.

In the context of political discourse, this means that there must be legitimacy and procedures or criteria that somehow mediate it, but after these procedures are performed and criteria met, there is no legitimacy transferred to rulers, who cannot claim to possess legitimacy at no point in time. On the contrary, legitimacy as resigning institutes a demand into the democratic sovereignty to open itself in all its acts to re-signing by each and every one. There is no democratic sovereignty without a certain opening to anyone to re-sign its laws and acts.

But equally, from the point of view of the people, all acts of law and order appear in need to be re-signed (always again) with a certain urgency by each and every one of them, because there is no democracy without re-signing. In this manner, legitimacy also becomes the principle of responsibility and responsiveness of the government and the people alike.

\section{Funding}

The author disclosed receipt of the following financial support for the research, authorship, and/or publication of this article: European Union’s Horizon 2020 research and innovation programme under the Marie Sklodowska-Curie grant agreement No 704479. 